\title{
SOME REMARKS ON THE LANGUAGE OF MODERN TAJIK PUBLIC INSCRIPTIONS (PART III)
}

Keywords: Tajik language, public inscriptions, multilingual texts

\begin{abstract}
The present article deals with the Tajik language used in modern public inscriptions (sign-boards, sign-posts, billboard advertisements, political banners, etc.) documented in about 400 photographs taken in Tajikistan by various individuals in recent years. Some sociolinguistic problems are discussed (especially in the case of multilingual inscriptions) as well as morphology, vocabulary, word-formation and syntax of the texts in question.
\end{abstract}

\section{Introduction}

The present article is a third one dedicated to the study of the Tajik language used in modern public inscriptions, i.e. sign-boards, sign-posts, billboard advertisements, political banners, etc. The first part (Gacek 2018a) focused on the languages other than Tajik used in this type of inscriptions. It also included a classification of the inscriptions based on their content. Then the phonetics, phonology, orthography and morphology (Gacek 2018b) of Tajik inscriptions were analyzed. In this part of the paper their vocabulary and syntax will be discussed.

\subsection{Vocabulary}

It is possible to indicate higher frequency words in the analyzed corpus. The following table lists those attested at least five times: ${ }^{1}$

1 The following results are based on all the inscriptions analyzed in the three parts of the present publication. 


\begin{tabular}{|c|c|c|c|c|c|}
\hline No. & Lexeme & $\begin{array}{l}\text { Number of } \\
\text { instances }\end{array}$ & No. & Lexeme & $\begin{array}{l}\text { Number of } \\
\text { instances }\end{array}$ \\
\hline 1. & Точикистон & 46 & 18. & Рахмон & 9 \\
\hline 2. & будан & 38 & 19. & a3 & 8 \\
\hline 3. & ба & 27 & 20. & Эмомалй & 8 \\
\hline 4. & ва & 20 & 21. & Роғун & 7 \\
\hline 5. & $\mathrm{y}$ & 20 & 22. & хуш & 7 \\
\hline 6. & чумхурй & 20 & 23. & бозор & 6 \\
\hline 7. & марказ & 19 & 24. & истиқлолият & 6 \\
\hline 8. & Наврӯз & 15 & 25. & ном & 6 \\
\hline 9. & дар & 12 & 26. & вазорат & 5 \\
\hline 10. & мо & 12 & 27. & ватан & 5 \\
\hline 11. & муборак & 12 & 28. & Душанбе & 5 \\
\hline 12. & шахр & 12 & 29. & Исфара & 5 \\
\hline 13. & сол & 11 & 30. & марказй & 5 \\
\hline 14. & бо & 10 & 31. & миллат & 5 \\
\hline 15. & давлатй & 10 & 32. & олй & 5 \\
\hline 16. & савдо & 10 & 33. & pȳ3 & 5 \\
\hline 17. & омадан & 9 & 34. & шумо & 5 \\
\hline
\end{tabular}

It should be noted that among the lexemes used most frequently, forms of Arabic origin constitute over $40 \%$ of the total number. Additionally, more than 400 words appear only once in the analyzed corpus.

As far as the origins of the lexemes used in the analyzed inscriptions are concerned, not surprisingly, there are a very large number of lexical items borrowed from Arabic (over 30\%), at least in the sense of their immediate sources. If hybrid forms with some Arabic element are also included, the numbers rise to over $40 \%$. This is consistent with the results for the most frequent lexemes (see above). As a comparison, words of entirely native origin form over $40 \%$ of the vocabulary and those with at least some native element, around 55\%.

These proportions are understandable, for as with all the varieties of Persian, Arabic was a major vocabulary-donor for over a thousand years. What makes Tajik different from Fārsi and Dari, is the impact of Russian, which was particularly strong during the 2oth century. Thus, Russian is certainly the second most important source of foreign vocabulary in modern Tajik. However, there is one interesting difference, that is while words taken from Arabic were mostly of Semitic origin (i.e. - in most cases - Arabic was both their immediate and original source), Russian mostly served as a vehicular language (the immediate source) in the transmission of words taken from other languages. Such words are often wide-spread internationalisms, e.g. институт [85], генералй [86] (originally from Latin), геодезй [87] 
$\left(\mathrm{Greek}^{2}\right)$, курорт [61] (German). Adding native suffixes like - $\bar{u}$ to words borrowed from (or via) Russian has been a widespread practice since the beginning of the $20^{\text {th }}$ century (see Rzehak 2001: 349 ).

Forms for which Russian served as a vehicular language constitute well over $10 \%$ of the analyzed vocabulary. A number of them clearly betray Russian as the intermediary on their journey into the Tajik language, mostly due to their phonetic features, e.g. литсей [88] from the Russian лицеци, with an affricate at the beginning of the second syllable. ${ }^{3}$ The Russian form was probably taken from the German Lyzeum (the primary source of the affricate), which in turn came from the Latin lyceum, with the original source being the Greek $\Lambda$ v́кıov (Vasmer 1986: 2.506). On other occasions, certain morphological features can be seen to play the same role, e.g. the final part of the form прокуратура [89] 'prosecutor's office', a derivative of прокуратор 'prosecutor', from either the Polish prokurator or the German Prokurator, both of which may be traced back to the Latin prōcūrātor (Vasmer 1986:3.374). Forms such as техника [90] show both the phonetic $(/-\mathrm{x}-/)^{4}$ and morphological (-a) impact of Russian. However, the Russian техника, in turn, was taken from the German Technik, which was based either on the Latin technica or - directly - on the Greek $\tau \varepsilon \chi v \iota \kappa \eta ́ / \tau \varepsilon \dot{\varepsilon} \chi \eta$ (Vasmer 1986: 4.54). In many other cases, there is no evidence that clearly points to Russian as a vehicular language and in these instances historical data, and a meticulous analysis of lexicographical works from the Soviet era, must be the basis for any conclusions.

Having discussed the role of Russian as a vehicular language, it has to be noted that words of Slavonic origin are scarce in the analyzed corpus. Nevertheless, some examples do exist, such as cyd [91] 'court, jury'. To this, the forms created in Russian, but based on elements from various origins, like the word комсомол [92], can be added.

There are isolated examples of words taken from other sources, such as the hybrid form чойхона [93] that contains the word for tea derived from the Chinese 茶.

\subsection{Word-formation}

Word-formational structure may be analyzed in both native and, to some extent, hybrid forms. Among the native forms are the following:

- suffixal derivatives with the adjectival suffixes -i (e.g. бостонй [55] 'ancient', варзишй [95] 'sports', Perry 2005: 426), -nok (бурднок [96] 'winning', Perry 2005: 428), -опа (куудакона [97] 'of children; adj. childish', Perry 2005: 424), the nominal suffix -i (dȳcmū [3] 'friendship', Perry 2005: 421), etc.;

- praefixal derivatives with bar- (бар-хост- [42] 'to stand up'), рег̌- (пешбаранда [98] 'leading'), be- (бебахо [72] 'priceless', Perry 2005: 431), ham- (хамватан [99], хамдиёp [100] both meaning 'compatriot', Perry 2005: 434), etc.;

2 It is possible to find in the analyzed corpus at least one form of Greek origin transmitted via Arabic, i.e. харитасозй [94].

3 The change of the written form from лицей to литсей is a purely orthographic phenomenon of the post-Soviet period.

4 The strongly articulated Russian / $\mathrm{h} /$ tends to be rendered by /x/ in Tajik, rather than /h/. 
- coordinate compounds (often with the joining element -o-), e.g. баробар [70] 'equal';

- determinative compounds, e.g. биморхона [101] 'hospital', бузургдоит [102] 'celebration', дастрас [103] 'available', донишкада [104] '[university] department, institute', наврас [105] 'a young person';

- more than one of the above-mentioned processes, e.g. бурунмарзй [99] 'foreign, external, expatriate' (determinative compound and suffixation), зироаткорй [85] 'cultivation'.

In some cases, the classification of the word-formational processes may be disputed, e.g. варзишгох [106] 'stadium' may be described as a determinative compound of the nouns варзиш 'sport, gymnastics' (itself a suffixal derivative, nomen actionis originated from the verbal stem варз-) and zox 'place'. However, alternatively, after analyzing its usage in the modern language, it may be more accurate to classify $20 x$ as a suffix or "virtual suffix" (Perry 2005: 436). The same phenomenon is observable in Persian (Rubinčik 2001: 148ff). The form донишгох [9, 47] 'university' is a similar example.

As far as the hybrid forms are concerned, most of them may be ascribed to one of two group: Arabic-native forms and Russian-native forms. The hybrid Arabic-Tajik forms are quite diversified. They may consist of an Arabic lexeme and Tajik prefix or suffix, e.g. бocaodam [107] 'happy', maъpuxū [108] 'historic', with another possibility being compounds formed by an Arabic and a native element, e.g. осорхона [109] 'museum'. Such compounds may be further developed by adding a native suffix, e.g. нусхабардорй [26] '[the act of] copying'.

In the case of Russian-native hybrid forms, statistically the native part is almost always the adjectival suffix $-\bar{u}$ or the homophonic nominal suffix, cf. канселяри [110] 'stationery', meampū [111] 'theatrical' and агентиu [87] 'agency', etc. This is a very different situation from the variety of possibilities in the case of the ArabicTajik forms.

\subsection{Syntax}

From the syntactical point of view, the analyzed texts may be divided into a number of types:

- single words (geographical names, names of institutions, names of products on offer), e.g. Иcфapa [112] 'Isfara (a city in northern Tajikistan)';

- izofat word groups consisting of two common nouns (the head and the modifier). These are mostly names or types of institutions, enterprises, etc., e.g. маркази бизнес [113] 'business centre';

- izofat word groups consisting of two nouns, where the modifier is a proper name. Structures of this type are understood as the introduction to the proper name of either an institution or an enterprise, e.g. Мехмонхонаи Точциистон [33] 'Tajikistan Hotel'; 
- izofat phrases consisting of a nominal head and an adjectival modifier, e.g. савдои бузург [114] (probably an indirect calque of the English 'supermarket'), * фурутигохи марказй $\bar{u}^{5}$ [1] 'central shop';

- more complex izofat phrases ('izofat chains'), e.g. фуруиши терминалхои маблаггузаронй [35] 'sale of ATMs', минтақаи назорати гумрукй [115] 'customs control zone'; ${ }^{\prime}$

- more complicated word groups (descriptions of various events, more detailed advertisements, etc.), which are mostly complex izofat constructions combined with prepositional phrases, often with elements joined by the conjunction $v a$, e.g. [MY] ЛОҚОТИ ПРЕЗИДЕНТ БО ХАМВАТАНОНИ БУРУНМАРЗЙ [99] 'meeting of the president with expatriate compatriots', зангхо ба Русия дар вақти шабона [34] 'phone calls to Russia at night', АГЕНТИИ ЗАМИНСОЗЙ, ГЕОДЕЗЙ ВА ХАРИТАСОЗИИ НАЗДИ ХУКУМАТИ ЧУМХУРИИ ТОЧИКИСТОН [87] 'Agency for construction, geodesy and cartography at the authorities of the Republic of Tajikistan';

- complete simple sentences, e.g. Пирујзии мо интихоби |иумо аст. [115] 'Our (my?) victory is your choice'. There are a considerable number of texts (mainly political slogans) belonging to this group that show ellipsis of the verb (3rd sg. praes. copulae), e.g. ТОЧИКИСТОНИ ОЗОДУ СОХИБИСТИҚЛОЛ ВАТАНИ МАХБУБИ ХАМАИ МО! [116] 'The free, independent Tajikistan [is] the beloved motherland of all of us!';

- complex sentences are rare, nevertheless, examples may be found, e.g. БА ДИҚҚАТИ ШАХРВАНДОН РАСОНИДА МЕШАВАД, КИ БАРОИ ГИРИФТАНИ МАЪЛУМОТ АЗ ШӮЬБАИ ҚАБУЛ МАСЛИХАТДИХЙ БА МУХОЧИРОНИ МЕХНАТЙ ТАНХО БА СОКИНОНИ ШАХРИ ДУШАНБЕ ИЧОЗАТ ДОДА МЕШАВАД [74] 'The citizens are hereby informed, that as far as acquiring information from the advisory office for the migrant workers is concerned, only the inhabitants of the city of Dushanbe are eligilble' or Pozyн манбаи алонашавандаи нур аст, ки Точикистонро дар овуши шарқи кухан ба ахтари хамешатобон | табдил хохад дод! [82] '[The city of] Royun is a notturning-evil(?) source of light that will change the Tajikistan in the embrace of the ancient East into an everglowing star';

- others, including meta-language texts and rough adaptations of foreign language texts, e.g. Точик Эйр [117] cf. Tajik Air, [Точцк] Содирот Бонк| Tojik Sodirot В[onk] [2] 'Tajik Export Bank', ДОРУХОНА 36,6 [118] 'Pharmacy 36,6', Автобуси дустии Точзкистону Хитой [3] 'bus of friendship of Tajikistan and China', MAKTABI MIJONAJI N 20 [4] 'Middle School No 20'.

Generally speaking, all the syntactical structures in the analyzed corpus are known in the Persian of Iran as well.

5 In fact, ФУРУШГОХИ МАРКАЗИ, as a stylized inscription, seems to lack vowel diacritics.

6 Original English translation accompanying the Tajik inscription. 


\section{Conclusions}

A quarter of a century after gaining independence, Tajik is clearly the dominant language of public inscriptions in Tajikistan. Russian is the second most common, and the use of English is also seen. The proportions between the languages used differs depending on the content of the texts.

With regard to phonetics and phonology, the influence of the Russian language on Tajik is still visible, at least from what may be deduced from the written forms. On the other hand, a tendency seems to exist to re-harmonize the Tajik vocabulary phonetically with that of the Persian of Iran.

In morphology, only minor (not to say negligible) differences may be observed, and - particularly in the verbal system - in the majority of cases only the forms common to all the varieties of Persian are used. None of the specifically Tajik tenses or moods are observed in the analyzed material. This is significant, as it is in the verbal system where particularly important differences between Tajik and Fārsi are most clearly seen.

Similarly, even where there are differences in the morphology of other parts of speech between Fārsi and Tojiki, the forms that exhibit these variations are not to be found in the analyzed corpus (e.g. the superlative grade of adverbs), except in certain minor details that would be insufficient to influence the mutual understanding between the users of both ethnolects in question. In other words, the Tajik language of public inscriptions, at least on the grammatical level, seems to be written in a form of pan-Persian koine and this is not a new tendency as a number of inscriptions are included in this study that were produced in the Soviet era. This situation is certainly in contrast to the native Tajik literature, where specifically Tajik forms are numerous.

This lack of specifically Tajik forms in the analyzed corpus is even more striking if its heterogeneous character is considered. Even when focusing on inscriptions that can be found in the Tajikistan of today, these, nevertheless, include those dating back to immediately after World War II, assuming that they still are extant. Moreover, the analyzed inscriptions include examples carved on stone monuments, as well as ad-hoc notices written with a pen on a piece of paper. Taking this into consideration, it can be concluded that the deliberate differentiation of Tajik from Persian by the adoption of many dialectal and even foreign (esp. Uzbek) elements into the standard proved to be much less successful in the case of public inscriptions, than, for example, in literary works (see Perry 1996: 282-283).

Of course, the potential benefits of using a common core of grammar, one shared with Dari and Fārsi, are reduced - at least in the case of inscriptions - by the different writing systems, as well as by the specifically Tajik vocabulary items. The latter is a particularly important factor, as what makes modern Tajik significantly different from Persian and Dari is the position of Russian. Numerous words present in the analyzed corpus are clearly loanwords transmitted into the language via Russian, yet while Russian has a central role as a vehicular language, words of Slavonic origin are scarce. 


\section{References}

Gacek T. 2018a. Some remarks on the language of modern Tajik public inscriptions (Part I). - SLing [= Studia Linguistica Universitatis Iagellonicae Cracoviensis] 135: 219-226.

Gacek T. 2018b. Some remarks on the language of modern Tajik public inscriptions (Part II). - SLing [= Studia Linguistica Universitatis Iagellonicae Cracoviensis] 135: 291-298.

Perry J.R. 1996. From Persian to Tajik to Persian: Culture, politics and law reshape a Central Asian language. - Aronson H.I. (ed.). Linguistic studies in the non-Slavic languages of the Commonwealth of Independent States and the Baltic Republics [= Non-Slavic Languages 8]. Chicago: 279-305.

Perry J.R. 2005. A Tajik Persian reference grammar. Leiden, Boston.

Rubinčik Yu.A. 2001. Grammatika Sovremennogo Persidskogo Literaturnogo Jazyka. Moskva. Rzehak L. 2001. Vom Persischen zum Tadschikischen. Sprachliches Handeln und Sprachplanung in Transoxanien zwischen Tradition, Moderne und Sowjetmacht (1900-1956). Wiesbaden.

Vasmer M. 1986. Etimologicheskij slovar' russkovo jazyka. [transl. O.N. Trubachev]. Moskva.

\section{Appendix}

\section{List of inscriptions}

Examples 1-32 are included in the first part of the article (Gacek 2018a) and those numbered 33-84 in the second one (Gacek 2018b).

85. Vazorat-i Kišovarzi 2014-7-5 Tajikistan (...)| ИНСТИТУТИ| ЗИРОАТКОРЙ | (...) | FARMING | INSTITUTE [at:] http://moa.tj/articles/instituti-ziroatkoriiakademiyai-ilm-oi-kishovarzii-to-ikiston/

86. Ozodagon 2013-5-2 Dushanbe ПРОКУРАТУРАИ ГЕНЕРАЛИИ| ЧУМХУРИИ ТОЧИКИСТОН [at:] http://www.ozodagon.com/9835-dodsiton-baroi-dimon-13-va-sherik15-soli-zindon-talab-kardaast.html

87. KaRiMi aLi 2010-2-22 Dushanbe АГЕНТИИ ЗАМИНСОЗЙ, ГЕОДЕЗЙ ВА ХАРИТАСОЗИИ НАЗДИ ХУКУМАТИ ЧУМХУРИИ ТОЧИКИСТОН [at:] http://www. panoramio.com/photo/39914556

88. vk.com 2014-10-12 Konibodom ВАЗОРАТИ | МАОРИФИ | ЧУМХУРИИ | ТОЧИКИСТОН | ЛИТСЕЙИ| № 1 | ШАХРИ КОНИБОДОМ, | ВИЛОЯТИ СУҒД [at:] http:// vk.com/wall-15216560? own $=1 \&$ offset $=140$

89. Tojnews 2014-12-6 Tajikistan МАРОСИМИ ЧОИЗАСУПОРИИ| ФЕДЕРАТСИЯИ ФУТБОЛИ ТОЧИКИСТОН 2014 || Руззи 5 декабри соли 20146 соати 14:00 | дар Мачмааи давлатии "Кохи Вахðат" [at:] http://www.tojnews.org/tj/news/bekhtarinkhoifutboli-tochikiston-dar-soli-2014-aks

90. ramon vila 2006-6-4 Dushanbe КОРХОНАИ МУШТАРАКИ| СОВМЕСТНОЕ ПРЕДПРИНЯТИЕ | РУССКИЕ МАШИНИ РТ | Продажа в кредит | Гарантия Сервис | Тюнинг |Хамчунин: ПАЗ, ЛиАЗ, ГолАЗ, Урал, экскаваторхо, техникаи сохтимониву рохсозй||СКЛАД ОАО „ГАЗ” В РЕСПУБЛИКЕ ТАДЖИКИСТАН (...) [at:] http://www.panoramio.com/photo/24576544

91. Radyo-i Ozodi 2010-5-7 Qurghonteppa Чумхурии Точикистон | СУДИ|ВИЛОЯТИ | [ХАТЛОН] [at:] http://rus.ozodi.org/content/article/24701067.html

92. Regar 2015-1-9 Kulob КИНОТЕАТРИ КОМСОМОЛ | [КОМСОМОЛ] КИНОТЕАТР [at:] http://www.regar.moy.su/photo/foto_tajikistan/2-8-0-0-5 
93. Stephen Willetts SteveW46243 2007-4-15 Dushanbe Чойхонаи POXAT [at:] https:// www.flickr.com/photos/sportyman531/6630831077/

94. kurbonashurov 2012-5-8 Yovon ТОЛОРИ ВАРЗИШЙ [at:] http://www.panoramio. com/photo/75043436

95. Шахриёр Ёров 2013-6-20 Dushanbe Амонати Бурдноки “ИҚБОЛ” | БУРДИ ОЛЙ| Бо гузоштани 10\$ | сохиби бурди (...) [at:] http://www.panoramio.com/photo/96821497

96. Afisha news 2014-10-11 Dushanbe МАҒОЗАИ КЎДАКОНА | ВАВҮSНОР [at:] http:// www.afisha-news.tj/catalog/ins/14/type/113/

97. ds-lands.com 2014-8-15 Dushanbe ЗИЁИЁН | НЕРУ ВА | ЧАВХАРИ | АҚЛОНИИ| МИЛЛАТ, | ҚУВВАИ | ПЕШБАР[АНДАИ] | ЧОМЕ[А] | ХАСТА[НД.] | ЭМОМАЛЙ PAХМOH [at:] http://ds-lands.com/photo/cities/dushanbe/10/

98. leonid_sokol 2012-11-24 Dushanbe [МУ]ЛОҚОТИ ПРЕЗИДЕНТ БО ХАМВАТАНОНИ БУРУНМАРЗЙ [at:] http://www.panoramio.com/photo/93729482

99. Ozodagon 2013-3-20 Dushanbe Навруз |муборак, | хамдиёрони | азиз! [at:] http:// www.ozodagon.com/9197-akso-shioroi-navrz-dar-kchavu-paskchaoi-dushanbe.html

100. Radyo-i Ozodi 2014-8-26 Tajikistan БИМОРХОНАИ МАРКАЗИИ НОХИЯИ Б. ҒАФУРОВ [at:] http://www.ozodi.org/content/article/26549417.html

101. Асатулло Узаев 2010-5-27 Isfara 2009- | Соли бузургдошти | Имоми Абзам (р.) [at:] http://www.panoramio.com/photo/36023520

102. oao Leitao JoaoleitaoTRAVEL 2012-6-12 Dushanbe ТЕ3, БОЛАЗЗАТ ВА ДАСТРАС| | БЫСТРО, ВКУСНО |И ДОСТУПНО || ТЕЗ, БОЛАЗЗАТ | ВА ДАСТРАС [at:] https:// www.flickr.com/photos/joaoleitao/8134252757/

103. unknown 2014-10-3 Dushanbe ДОНИШКАДАИ МОЛИЯ ВА ИҚТИСОДИ ТОЧИКИСТОН [at:] http://feit.tj/tj/about_the_university/history/

104. Dushanbemaorif 2014-10-25 Dushanbe МАРКАЗИ КЎДАКОН ВА НАВРАСОНИ ШАХРИ ДУШАНБЕ [at:] http://www.dushanbemaorif.tj/index2.php?padmenu=10 \&lang $=\mathrm{tj} \&$

105. Michael Shamshidov 2014-10-9 Khujand ВАРЗИШГОХ [at:] http://www.orexca.com/ photogallery/387

106. ackoreo 2011-10-7 Qurghonteppa ОЯНДАИ | БОСАОДАТИ | КИШВАР | БА ЧАВОНОН | МАНСУБ АСТ. | (...) [at:] http://www.panoramio.com/photo/61364801

107. ackoreo 2011-10-7b Qurghonteppa ИСТИҚЛОЛИЯТИ ДАВЛАТЙ ДАСТОВАРДИ МУХИМТАРИН | ВА БУЗУРГТАРИНИ ТАЪРИХИ НАВИНИ ХАЛҚИ | ТОЧИКИСТОН МЕБОШАД. | ЭМОМАЛЙ РАХМОН [at:] http://www.panoramio. com/photo/61364801

108. Steve Evans babasteve 2008-6-13 Khujand ОСОРХОНАИ ТАЪРИХИИ| ВИЛОЯТИ СУҒД || ИСТОРИЧЕСКИЙ МУЗЕЙ|СОГДИЙСОЙ ОБЛАСТИ|| HISTORICAL MUSEUM | OF SUGHD REGION [at:] https://www.flickr.com/photos/babasteve/3322753282

109. klik.tj Dushanbe Клик|МОЛХОИ КАНСЕЛЯРЙ ВА КИТОБ| www.klik.tj [at:] http:// kilk.tj/branches/

110. ds-lands.com 2014-8-15 Dushanbe (...)| ОҒОЗИ 71-УМИН МАВСИМИ ТЕАТРЙ "Шайхурраис Абуалй ибни Сино" [at:] http://ds-lands.com/photo/cities/dushanbe/10/

111. Асатулло Узаев 2010-5-29 Isfara Исфара [at:] http://www.panoramio.com/photo/ 36098063

112. ABLV Bank 2012-2-28 Dushanbe маркази бизнес [at:] http://www.ablv.com/content/ 2/0/4/5/2/8d3cc746/Dushanbe700.jpg

113. paykar.tj 2007-6-22 Dushanbe ПайКар | СУПЕРМАРКЕТ|САВДОИ БУЗУРГ| SUPЕRMARKET [at:] http://www.panoramio.com/photo/15668720 
114. jahongard 2012-9-7 Dushanbe МИНТАҚАИ НАЗОРАТИ ГУМРУКИ| СUSTOMS CONTROL ZONE [at:] http://www.panoramio.com/photo/80160075

115. Radyo-i Ozodi 2014-12-22 Kulob ПИРӯЗИИ МО ИНТИХОБИ | ШУМО АСТ. | ЭМОМАЛЙ РАХМОН [at:] http://www.ozodi.org/content/illegal-religious-study-inkulob/26756801.html

116. Dastbadast 2011-11-29 Dushanbe ТОЧИКИСТОНИ ОЗОДУ СОХИБИСТИҚЛОЛ| ВАТАНИ МАХБУБИ ХАМАИ МО! [at:] http://www.dastbadast.tj/aks/298-teatr.html

117. husrav 2012-3-5 Dushanbe ТОЧИК ЭЙР | ТАJIК AIR [at:] http://www.panoramio. com/photo/68032488

118. Fisher_Ү 2010-12-11a Dushanbe ДОРУХОНА 36,6 [at:] http://www.panoramio.com/ photo/62256924 
